OPEN ACCESS

Edited by: Jesse G. Dillon, California State University, Long Beach, USA

Reviewed by:

Hugh Morgan,

University of Waikato, New Zealand

Marcus A. Horn,

Leibniz University of Hannover,

Germany

*Correspondence:

Ruben Sommaruga

ruben.sommaruga@uibk.ac.at;

Cristina Dorador

cristina.dorador@uantof.c

Specialty section:

This article was submitted to

Extreme Microbiology,

a section of the journa

Frontiers in Microbiology

Received: 28 January 2016 Accepted: 06 June 2016

Published: 21 June 2016

Citation:

Aguilar P, Acosta E, Dorador C and

Sommaruga $R$ (2016) Large Differences in Bacterial Community Composition among Three Nearby Extreme Waterbodies of the High Andean Plateau.

Front. Microbiol. 7:976. doi: 10.3389/fmicb.2016.00976

\section{Large Differences in Bacterial Community Composition among Three Nearby Extreme Waterbodies of the High Andean Plateau}

\author{
Pablo Aguilar1,2,3, Eduardo Acosta ${ }^{2,3}$, Cristina Dorador ${ }^{2,3 *}$ and Ruben Sommaruga ${ }^{1 *}$ \\ ${ }^{1}$ Lake and Glacier Ecology Research Group, Institute of Ecology, University of Innsbruck, Innsbruck, Austria, ${ }^{2}$ Laboratory of \\ Microbial Complexity and Functional Ecology, Antofagasta Institute, University of Antofagasta, Antofagasta, Chile, ${ }^{3}$ Centre \\ for Biotechnology and Bioengineering, Universidad de Chile, Santiago, Chile
}

The high Andean plateau or Altiplano contains different waterbodies that are subjected to extreme fluctuations in abiotic conditions on a daily and an annual scale. The bacterial diversity and community composition of those shallow waterbodies is largely unexplored, particularly, of the ponds embedded within the peatland landscape (i.e., Bofedales). Here we compare the small-scale spatial variability $(<1 \mathrm{~m})$ in bacterial diversity and community composition between two of those ponds with contrasting apparent color, using 454 pyrosequencing of the $16 \mathrm{~S}$ rRNA gene. Further, we compared the results with the nearest $(80 \mathrm{~m})$ main lagoon in the system to elucidate the importance of different environmental factors such as salinity and the importance of these ponds as a source of shared diversity. Bacterial diversity was higher in both ponds than in the lagoon and community composition was largely different among them and characterized by very low operational taxonomic unit sharing. Whereas the "green" pond with relatively low dissolved organic carbon (DOC) concentration (33.5 $\mathrm{mg} \mathrm{L}^{-1}$ ) was dominated by Proteobacteria and Bacteroidetes, the one with extreme DOC concentration (424.1 $\mathrm{mg} \mathrm{L}^{-1}$ ) and red hue was dominated by Cyanobacteria. By contrast, the lagoon was largely dominated by Proteobacteria, particularly by Gammaproteobacteria. A large percentage (47\%) of all reads was unclassified suggesting the existence of large undiscovered bacterial diversity. Our results suggest that even at the very smallscale spatial range considered, local environmental factors are important in explaining differences in bacterial community composition in those systems. Further, our study highlights that Altiplano peatland ponds represent a hitherto unknown source of microbial diversity.

Keywords: bacterial diversity, pyrosequencing, 16S rRNA gene, DOC, ponds, Salar de Huasco, Altiplano

\section{INTRODUCTION}

Extreme ecosystems are characterized by high or low, and sometimes largely fluctuating, values of at least one environmental factor such as, for example, UV radiation, temperature, $\mathrm{pH}$, salinity, or pressure (Seufferheld et al., 2008). Such environments are often dominated by microbes that show a high degree of adaptation and enable them to establish a population (Goordial et al., 2016). The Andean Altiplano is a highland plateau with an average altitude of $4000 \mathrm{~m}$ located between ca. $15^{\circ}$ and $22^{\circ} \mathrm{S}$ (Risacher et al., 2003) and within a semi-arid 
region (Garreaud et al., 2003). This area presents several extreme environmental conditions including high midday solar (UV) radiation (600-1100 $\mathrm{W} \mathrm{m}^{-2}$ ), extreme daily temperature changes $\left(-10\right.$ to $\left.+25^{\circ} \mathrm{C}\right)$, negative water balance, low atmospheric pressure (40\% lower than that at sea level), and a wide range of salinity ranges (from freshwater to saturated saltwater within the same basin; Dorador et al., 2010, 2013). There are several closed hydrographic basins in this area, which together show significant variation in physicochemical and geomorphological characteristics (Risacher et al., 2003). One of those basins, the Salar de Huasco, Chile, includes the permanent waters of the homonymous lagoon and a complex mosaic of streams, peatlands, salt crusts, and ponds (Vila et al., 2007; Dorador et al., 2013). Studies in the lagoon of Salar de Huasco have shown that this ecosystem presents a large number of novel bacterial clusters and 16S rRNA gene phylotypes, including Cyanobacteria (Dorador et al., 2008b), Archaea (Dorador et al., 2010), Bacteroidetes (Dorador et al., 2009), and ammoniaoxidizing bacteria (Dorador et al., 2008a).

Ponds are small shallow and stagnant waterbodies that hold water permanently or temporarily and have been useful to study ecological patterns of community assembly and ecoevolutionary feedbacks (De Meester et al., 2005). They can be found in environments ranging from polar deserts to tropical rainforests (Céréghino et al., 2008). Due to their patchy geographical distribution, the importance of ponds in regional- and large-scale biogeochemical studies remains elusive (Holgerson, 2015).

Microorganisms living in ponds have been identified as key components in the biogeochemical cycling of carbon, nitrogen, and other elements (Hahn, 2006). The factors that shape the bacterial community composition (BCC) of ponds and lakes have been analyzed at different spatial scales ranging from $<1$ to $>2500 \mathrm{~km}$ (e.g., van der Gucht et al., 2007). This study, for example, revealed that local environmental factors are more important than spatial distance in explaining changes in
BCC. Similar studies, however, at spatial scales $<0.1 \mathrm{~km}$ are rare for stagnant freshwaters because seldom do they lie so close together. One exception are the ponds found embedded within the peatland (locally termed Bofedales) landscape in the Altiplano. Bofedales are peat-accumulating systems dominated by cushion plant communities with relatively high organic carbon production (Cooper et al., 2015).

In this study, we assessed the BCC and diversity using NGS in two nearby $(<1 \mathrm{~m})$ small peat ponds and compared them with that of the lagoon of Salar de Huasco, located ca. $80 \mathrm{~m}$ apart from the ponds. Though the ponds had a conspicuously different color, we expected to find a similar BCC considering their close proximity and the same surrounding environmental matrix (i.e., the bofefal). By contrast, we expected to find a different BCC in the lagoon due to its saline character (Dorador et al., 2008a).

\section{MATERIALS AND METHODS}

\section{Study Area and Sampling}

The Salar de Huasco $\left(20^{\circ} 18^{\prime} 18\right.$ S, 68 $50^{\prime} 22$ W, Chile, Figure 1A) is located at $3800 \mathrm{~m}$ above sea level and has a mean air temperature and precipitation of $5.0^{\circ} \mathrm{C}$ and $150 \mathrm{~mm}$ year ${ }^{-1}$, respectively (Risacher et al., 2003). Bofedales develop where groundwater keeps the ecosystem permanently wet close to streams and lakes (Cooper et al., 2015). The water sources of these systems are freshwater and low salinity groundwater originating from glacier streams, snowmelt, and rain (Squeo et al., 2006). In August 2013 (i.e., during the dry season), water samples were collected from two shallow (ca. $20 \mathrm{~cm}$ depth) ponds taking care of not disturbing the sediment and avoiding algal clumps. The ponds had different apparent color (hereafter: E72-Red and E73Green) and light penetrated to the bottom. They were embedded within the Bofedales landscape and located just $<1 \mathrm{~m}$ apart (Figure 1B). Samples were also collected from the lagoon of the

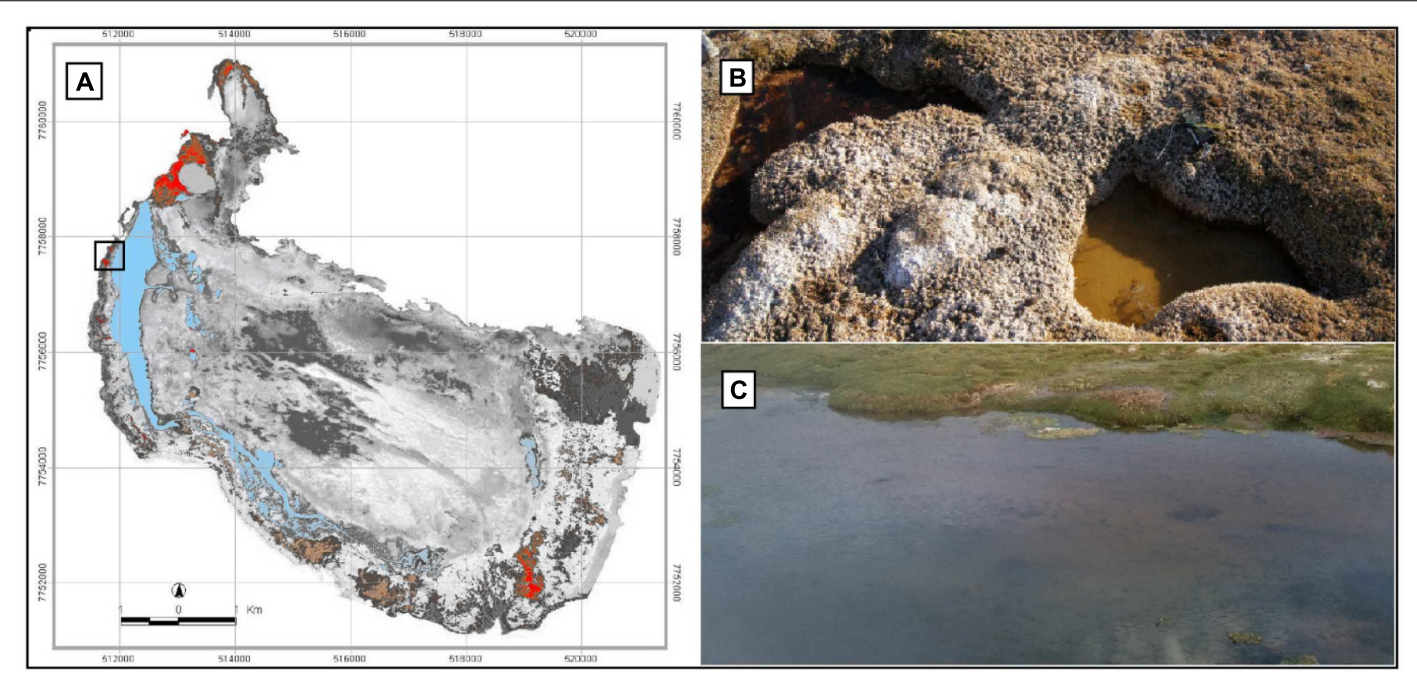

FIGURE 1 | Sampling sites at the Salar de Huasco. (A) Map of Salar de Huasco showing the sampling sites at station H3 (black square). Peatlands ("Bofedales") are showed in red/brown and water bodies in blue. (B) The red (left side) and green pond (right side). (C) The lagoon at station H3 (black square in (A)). 
Salar de Huasco (hereafter: E74-Blue) close to the station H3 in Dorador et al. (2008a), which was ca. $80 \mathrm{~m}$ apart from the ponds (Figure 1C). Lamentably, due to a sudden dust storm, no more samples were possible to collect from those remote systems. Water samples were filtered in situ using $0.22 \mu \mathrm{m}$ Sterivex filters (Millipore) until clogging was observed and then, the filters were stored in lysis buffer $(2 \mathrm{ml})$ [50 mM Tris- $\mathrm{HCl}(\mathrm{pH} 9)$, $20 \mathrm{mM}$ EDTA, $400 \mathrm{mM} \mathrm{NaCl}$, and $0.75 \mathrm{M}$ sucrose], immediately placed on ice, and stored at $-20^{\circ} \mathrm{C}$ in the laboratory until DNA extraction.

\section{Physicochemical Parameters}

In situ measurements of temperature and $\mathrm{pH}$ were done with a portable $\mathrm{pH}$ meter and coupled thermometer (HI9126, Hanna Instruments), whereas electrical conductivity was measured with a portable conductivity meter (Orion Star A322, Thermo Scientific). Due to the shallowness of the systems, only one measurement was done. Samples were also collected in parallel for the analysis of major anions (nitrate, chloride, and sulfate) and cations (potassium, sodium, calcium, and magnesium) by ion chromatography (Dionex ICS-1100/1000). Additional samples were collected in precombusted $\left(4 \mathrm{~h}\right.$ at $\left.450^{\circ} \mathrm{C}\right)$ glass bottles for the analysis of dissolved organic carbon (DOC) and dissolved nitrogen $(\mathrm{DN})$. These samples were filtered in situ through two pre-combusted GF/F filters (Whatman). The filtrate was acidified with $\mathrm{HCl}$ to $\mathrm{pH} 2$ and analyzed later at the laboratory in Innsbruck with a Shimadzu TOC-Vc series equipped with a total nitrogen module. An appropriate dilution (three parallels) was done with Milli-Q water of low carbon content to fit the calibration range. The instrument for DOC analysis was calibrated with potassium hydrogen phthalate, while calibration for the DN was done with potassium nitrate. Three to five subsamples were analyzed for each sample and for a consensus reference material (CRM) for DOC (batch 5 FS-2005: $0.57 \mathrm{mg}$; provided by RSMAS/MAC, University of Miami) that was run in parallel on each occasion. Results differed from the CRM given value by $5 \%$, and the coefficient of variation among subsamples was $<2 \%$. From the same filtrate, spectral characteristics of the chromophoric dissolved organic matter (CDOM) were measured in a double-beam spectrophotometer (Hitachi). We calculated the ratio of the slopes $\left(S_{R}\right)$ of log-transformed absorption over two wavelength regions (275-295 and 350-400 nm) as a proxy (inversely related) of the dominant molecular weight of CDOM (Helms et al., 2008).

\section{DNA Extraction and 454 Pyrosequencing}

Genomic DNA was extracted using a PowerBiofilm DNA Isolation kit (Mo Bio Laboratories Inc.) following the manufacturer's protocol. The concentration and quality of DNA were measured with a Nanodrop spectrophotometer (Nanodrop 8000, Thermo Scientific). The extracted DNA (300 ng) was used as template for 16S rRNA gene fragments amplification and further pyrosequencing done at the Research and Testing Laboratory (Lubbock, TX, USA) using a Roche 454 FLX platform with the universal primers 28F $\left(5^{\prime}\right.$-GAGTTTGATCMTGGCTCAG-3') and 519R (5'GWATTACCG CGGCKGCTG-3'; Turner et al., 1999). Raw pyrosequencing reads have been deposited in the sequence read archive (SRA) of NCBI under accession number SRP068879.

\section{Data Analysis}

The raw pyrosequencing dataset was processed using Mothur (v. 1.35.1) following Schloss 454 SOP protocol $^{1}$ (Schloss et al., 2011). The Shhh.flow command was used as the first step to reduce sequencing noise, and the trim.seqs command was used to trim the reads with the average quality score of 25 , and to eliminate any reads that was not in the 100-400 bp range. Reads were aligned to the SILVA-compatible alignment database using align.seqs command. A pre-cluster step was applied to further reduce sequencing noise. Chimeras were detected and removed using UCHIME. The SILVA119 database was used to classified reads with a confidence threshold of $80 \%$. The remove.lineage commands were used to identify and remove mitochondrial, chloroplasts, Archaea, Eukarya, and unknown contaminants. Reads were assigned to operational taxonomic units (OTU) at the $3 \%$ level of divergence using the cluster.classic command. To test for differences between the water bodies, all samples were randomly subsampled to the same size according to the sample with the smallest number of reads. Rarefaction curves and alpha diversity metrics such as Chaol, Fisher, Shannon $\left(H^{\prime}\right)$, and Simpson $(1-D)$ including their bootstrap confidence intervals (9999) were calculated using PAST (Hammer et al., 2001). Representative reads of each OTU was compared with GenBank using BLASTn tool to determine the novelty (or uniqueness) of reads.

The Mothur shared file was converted to a Cytoscape network file using a custom R script (Neave et al., 2014). The dataset was used with the total number of OTUs, and singleton reads were removed to reduce complexity. The network was constructed as a bipartite graph, containing both OTUs and sites as nodes, and edges were drawn between OTUs and the site in which they were detected. The weight of the edge was proportional to the abundance of the OTU. The networks were visualized using Cytoscape v3.2.12. Beta diversity metrics were calculated using Unifrac (Lozupone and Knight, 2005), implemented in Mothur, to assess the similarity between communities membership (unifrac.unweighted command) and structure (unifrac.weighted command). Relaxed neighbor joining phylogenetic tree was done using CLEARCUT (Evans et al., 2006) implemented in Mothur, and visualized through iTOL ${ }^{3}$ (Letunic and Bork, 2011).

\section{RESULTS}

\section{Physicochemical Characteristics}

Water temperatures measured at midday were 15.3 and $11.3^{\circ} \mathrm{C}$ in E72-Red and E73-Green ponds, respectively, whereas in the lagoon (E74-Blue), it was $14.3^{\circ} \mathrm{C}$. The $\mathrm{pH}$ in all systems was alkaline with the highest value found in pond E72-Red (8.8) followed by the lagoon E74-Blue and pond E73-Green

\footnotetext{
${ }^{1}$ http://www.mothur.org/wiki/454_SOP

${ }^{2}$ http://cytoscape.org/

${ }^{3}$ http://itol.embl.de/
} 
(Table 1). By contrast, the conductivity was highest in the lagoon $\left(40.35 \mathrm{mS} \mathrm{cm}^{-1}\right)$, followed by the green $\left(28.75 \mathrm{mS} \mathrm{cm}^{-1}\right)$ and the red pond $\left(8.89 \mathrm{mS} \mathrm{cm}^{-1}\right)$. In agreement with the conductivity values, the ionic concentration followed the same trend, though there were also differences in ionic composition (Supplementary Figure S1). For example, the lagoon had a higher dominance of chloride than the ponds. The concentration of DOC was highest in the pond E72-Red with $424.1 \mathrm{mg} \mathrm{L}^{-1}$ and it was one order of magnitude higher than in the green pond and the lagoon (Table 1). DN was again highest in the pond E72-Red (19.4 $\left.\mathrm{mg} \mathrm{L}^{-1}\right)$, but the concentration in the lagoon was higher $\left(2.7 \mathrm{mg} \mathrm{L}^{-1}\right)$ than in pond E73-Green $\left(1.5 \mathrm{mg} \mathrm{L}^{-1}\right)$. The slope ratio $\left(S_{R}\right)$ for CDOM (Supplementary Figure S2) was highest in the lagoon (2.01), followed by the ponds E73-Green (0.98) and E72-Red (0.89).

\section{Bacterial Diversity}

After quality control, we obtained 5921 reads from all samples, the highest number of reads was detected in the lagoon $(3022$ reads), followed by pond E73-Green (1827 reads) and pond E72-Red (1072 reads). Thus, it was subsampled to 1072 reads. The highest OTU number was recovered from pond E73-Green with a total of 371 followed by E72-Red (359) and E74-Blue samples (157). The pond E73-Green showed also the highest alpha diversity metrics in almost all indexes (Table 2), while the lowest were found in the lagoon. However, the extrapolated richness (Chaol) was higher in pond E72-Red. The rarefaction curves of the OTUs indicated that diversity was not completely sampled in all three systems (Supplementary Figure S3).

\section{Bacterial Community Composition}

In general, ponds shared just a few OTUs between them, but the shared fraction between the ponds and the lagoon was even lower, showing that virtually each system had distinct bacterial communities (Figure 2). This was supported by the UniFrac results that showed significant differences $(P<0.001)$ in community membership and structure among samples (Supplementary Table S1). Only three OTUs were shared by all samples and represented by Seohaeicola, Loktanella, and
Halomonas. The phylogenetic distribution of taxa found in the samples showed that the pond E72-Red was dominated by OTUs which were closely related (Supplementary Figure S4). There was no representative in this part of the phylogenetic tree that was shared with the lagoon and only a few with pond E73-Green. The latter was more evenly represented on the phylogenetic tree, which is in agreement with the higher diversity found in this system. In total, we identified 23 different bacterial phyla (Figure 3), though at the genus level, $47 \%$ of reads from all samples were unclassified. The most abundant phylum (\% relative abundance) in pond E72-Red was Cyanobacteria (41\%), followed by Proteobacteria (38.1\%) and Firmicutes (5.9\%). Within the reads recovered and classified as Cyanobacteria, 50\% were unclassified (Supplementary Table S2). The filamentous cyanobacterium Arthrospira (15.6\%) was dominant in this group of reads. Others cyanobacterial taxa identified with $<2 \%$ of relative abundance were Leptolyngbya, Oscillatoria, and Nodularia. The prevailing Proteobacteria class in this pond was Alphaproteobacteria (20.4\%) and $85 \%$ of this class was represented by members of Rhodobacteraceae family.

In pond E73-Green, the most abundant phylum was Proteobacteria (52\%), followed by Bacteroidetes (8.3\%) and Actinobacteria (7.7\%). Within Proteobacteria (Supplementary Table S3), the most abundant class was Alphaproteobacteria (21.4\%) with Hyphomicrobium, Rhodobacter, and Pedomicrobium as dominant taxa. The second most abundant class was Betaproteobacteria (15\%) that was mainly represented by Hydrogenophaga and an unclassified group. Further, we detected the presence of Gammaproteobacteria, Deltaproteobacteria, and Epsilonproteobacteria. Within Bacteroidetes, Flavobacterium was the most abundant genus.

The main groups in the lagoon (E74-Blue) were Proteobacteria (76.1\%), Bacteroidetes (14.5\%), and Actinobacteria (4.7\%). The most important taxa were the Gammaproteobacteria Halomonas and Spiribacter (Supplementary Table S4). All reads classified as Alphaprotebacteria (the second most abundant class) were associated to the Rhodobacteraceae family, though were unclassified to genus level. High percentages (94.6\%) of

TABLE 1 | Main physicochemical parameters of the three systems.

\begin{tabular}{|c|c|c|c|c|c|}
\hline System/Code & Water temperature $\left({ }^{\circ} \mathrm{C}\right)$ & $\mathrm{pH}$ & Conductivity $25^{\circ} \mathrm{C}\left(\mathrm{mS} \mathrm{cm}^{-1}\right)$ & $\mathrm{DOC}\left(\mathrm{mg} \mathrm{L}^{-1}\right)$ & $\mathrm{DN}\left(\mathrm{mg} \mathrm{L}^{-1}\right)$ \\
\hline Pond E73-Green & 11.3 & 8.1 & 28.75 & 33.5 & 1.5 \\
\hline
\end{tabular}

DN, dissolved nitrogen; DOC, dissolved organic carbon.

TABLE 2 | Total number of reads, OTUs number, and diversity metrics for the three systems.

\begin{tabular}{lcccccc}
\hline System/Code & Number of reads & Number of OTUs & Chao1 (CI) & Fisher's (CI) & Shannon (CI) & Simpson (CI) \\
\hline Pond E72-Red & 1072 & 359 & $817(740.2-894.3)$ & $189.3(177.3-201.2)$ & $4.7(4.6-4.9)$ & $0.96(0.95-0.97)$ \\
Pond E73-Green & 1827 & 493 & $668(605.5-730.5)$ & $201(188.8-213.1)$ & $5.3(5.2-5.4)$ & $0.99(0.98-0.99)$ \\
Lagoon E74-Blue & 3022 & 245 & $311(266.3-355.8)$ & $50.7(46.3-55.0)$ & $3.5(3.4-3.6)$ & $0.93(0.92-0.94)$
\end{tabular}

Cl: bootstrapped confidence interval at 95\%. 


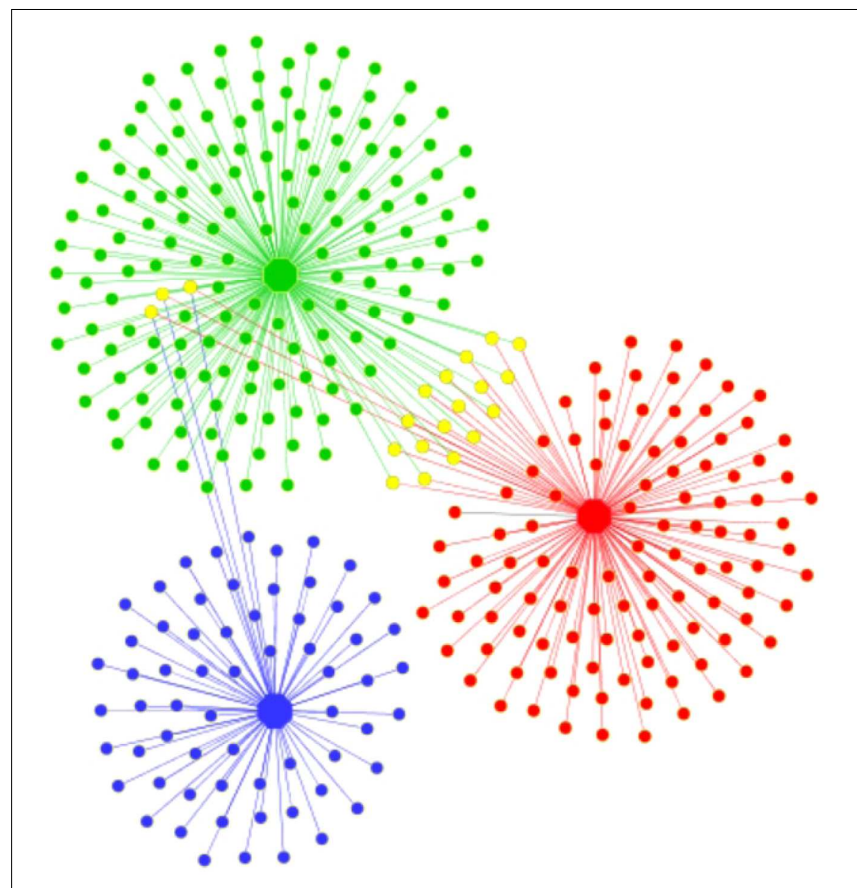

FIGURE 2 | Network analyses of operational taxonomic units (OTUs) from bacterial communities of Pond E72-Red (red dots), Pond E73-Green (green dots), and the lagoon E74-Blue (blue dots). Shared OTUs are indicated by yellow dots.

the reads classified as Betaproteobacteria and were related to GKS98 freshwater group (Zwart et al., 2002). The main reads of Bacteroidetes were related to Psychroflexus and other unclassified taxa.
The comparison of all reads from our study with those in GenBank (Supplementary Figure S5) indicated that the pond E72-Red had the highest percentage (11.6\%) of novel reads (i.e., $<97 \%$ similarity), followed by the lagoon (10\%), and the pond E73-Green (7.9\%).

\section{DISCUSSION}

The three studied systems differed strongly in several physicochemical characteristics and although environmental factors have a prominent role in shaping microbial biogeographic patterns (Hanson et al., 2012), this was unexpected considering they are located next to each other, particularly, the two ponds. All systems had alkaline $\mathrm{pH}$ which is typical for waterbodies in the Altiplano (Marquez-Garcia et al., 2009), though the groundwater feeding the bofedales is typically acidic (Cooper et al., 2015). The different conductivity and ionic composition of the lagoon indicate that the source of water is different to that of the ponds. However, between the two close ponds, there was also a large difference (ca. threefold) in conductivity, which is probably explained by in-pond processes rather than by a different groundwater source. One particularly striking difference between the two ponds and with the lagoon was in DOC concentration. Indeed, the DOC concentration measured in pond E72-Red was far above (by $92 \mathrm{mg} \mathrm{L}^{-1}$ ) the highest value reported for aquatic systems (Sobek et al., 2007). Thus, this type of pond that shows disproportionately high carbon and nitrogen values compared to the surroundings can be considered biogeochemical hotspots in this area (McClain et al., 2003). What process explains the large difference in DOC concentration between two systems that are just $<1 \mathrm{~m}$ apart is intriguing. One

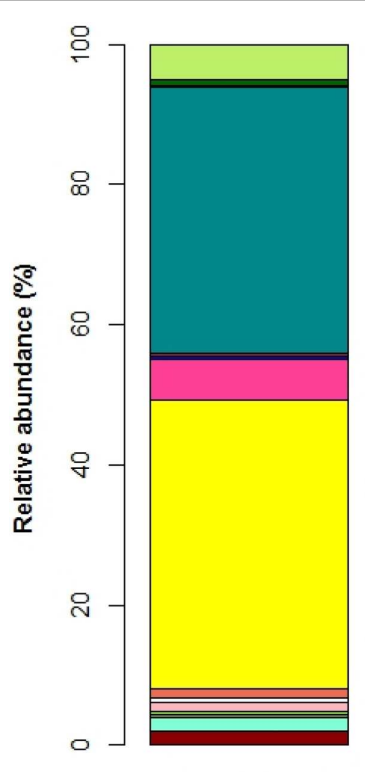

E72-Red pond

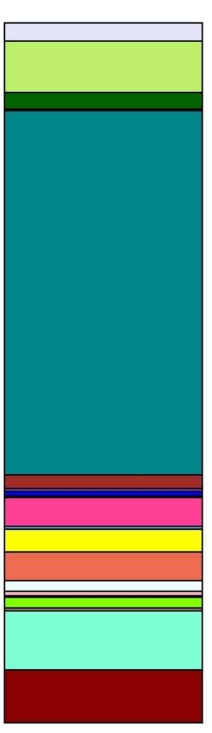

E73-Green pond
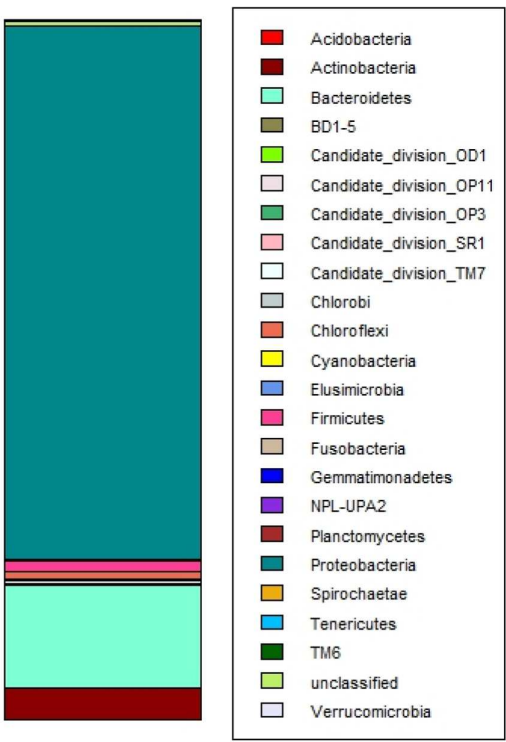

E74-Blue lagoon

FIGURE 3 | Relative abundance of the different phyla (and candidate divisions) for the three sites. 
possibility is that it is related to the difference dominance by primary producers in these two systems. Though we did not measure chlorophyll-a as a proxy for algal biomass, visual observation of the ponds indicated that E73-Green presented suspended microalgae, while the pond E72-Red did not (but see below dominance by cyanobacteria). By contrast, in the latter pond, there was a developed benthic mat. Another possible explanation is the occurrence of animal droppings from wild vicuña (Vicugna vicugna) and guanaco (Lama guanicoe) that are inhabitants of the Altiplano (Squeo et al., 2006). Though we observed animal droppings in several areas, they were neither found inside, nor in the close surroundings of those specific ponds, at least at the time of sampling. Nevertheless, the lower slope absorbance ratios $\left(S_{R}\right)$ of the ponds than in the lagoon (Supplementary Figure S2) indicate the major influence of the peat and the predominance of high molecular weight DOM in these ponds.

Another important difference between the ponds was in their apparent water color. The red hue in pond E72 might be partially associated to high carotenoid concentrations synthesized by phototrophic organisms to minimize damage by UV radiation. This is reasonable because even if the high DOC concentration in this pond will strongly absorb these damaging wavelengths, the shallowness of the system (ca. $20 \mathrm{~cm}$ ) and the occurrence of strong winds will expose microorganisms to the high incident solar UV radiation existing at this altitude. Another possibility is that the apparent red hue is given by the presence of iron. At the high $\mathrm{pH}$ observed in the pond (8.8), iron will be mostly insoluble and in colloidal form, but the high organic carbon content and the presence of a benthic mat could produce reduced conditions where iron becomes more soluble.

The different environmental characteristics of the systems were also reflected in a contrasting BCC found between the two ponds and at the same time, in comparison with that of the lagoon. Unexpectedly, the pond E72-Red was largely dominated by cyanobacteria followed by Proteobacteria (Figure 3). The relative dominance of cyanobacteria in this pond is atypical when compared with previous results for other water bodies in the Altiplano (Dorador et al., 2008b). A large proportion (120 out 140) of the OTUs corresponding to Cyanobacteria was unclassified suggesting a large, unexplored diversity. The known OTUs were related with Arthrospira, Oscillatoria, and Leptolyngbya which are also typically found in other high salinity ecosystems, such as in the Salton Sea, a lake located in the Southern California desert (Wood et al., 2002). Whether the cyanobacterial dominance in this pond (probably also in the benthic mats) could relate to the extreme DOC concentration found remains to be demonstrated. High DOC release rates by benthic cyanobacteria, however, are known (Brocke et al., 2015). Another important bacterial component in this pond was the Alphaproteobacteria, particularly members of the Rhodobacteraceae, but again with an unknown affiliation at the genus level. This family comprises aerobic photo- and chemoheterotrophs, as well as non-sulfur photosynthetic bacteria thriving in anaerobic habitats (Pujalte et al., 2014), which was not the case here.
The most abundant phyla in pond E73-Green were Bacteroidetes and Proteobacteria, the latter being the dominant phylum in the lagoon too. The same relative dominance has been observed in several water bodies of the Altiplano (Demergasso et al., 2010; Dorador et al., 2013), although direct comparison should be done with caution considering the different resolution level of the methods used (NGS vs. DGGE or clone libraries). Both Flavobacterium in E73-Green and Psychroflexus in E74Blue were the most abundant Bacteroidetes taxa and they are reported to be common in several aquatic environments of the Altiplano (Dorador et al., 2009) and other (hypersaline lakes). For example, Psychroflexus tropicus is an obligately halophilic bacterium found in a Hawaiian hypersaline lake (Donachie et al., 2004). By contrast, in pond E72-Red, $<2 \%$ of the reads belonged to Bacteroidetes and the few OTUs found were different from those previously known for this area (Dorador et al., 2009). It is difficult to pinpoint the cause for the different contribution of Bacteroidetes in these systems, but many members of this phylum are known to live associated with particles (Kirchman, 2002), which were present in the lagoon (high turbidity) and in the green pond (algal detritus and microalgae), but not in the red one, where only flocs at the very surface were observed. In particular, members of the Cytophaga-Flavobacteria are chemoorganotrophic and able to degrade complex organic polymers such as cellulose from algal origin (Kirchman, 2002).

Interestingly, in all three systems, members of the candidate division OD1 (Parcubacteria) were found suggesting the existence of suboxic conditions (Peura et al., 2012), typically found in waterbodies at this high altitude (Dorador et al., 2009) and probably even more in such high DOC environments. This phylum has recently been proposed to be symbionts of other bacteria (Nelson and Stegen, 2015). Further, it is important to highlight the presence in all samples of different OTUs considered part of the recently described candidate phyla radiation (CPR, e.g., OD1, OP11, SR1, and TM7; Brown et al., 2015) and also others described as microbial dark matter (e.g., OP3 and TM6; Rinke et al., 2013). Generally, CPR genomes are small (determined using single-cell genomics) and lack several biosynthetic pathways commonly present in bacteria, so that they seem to need other organisms for survival. Therefore, these ponds would be an interesting site to study the specific adaptations and diversity of this elusive subdivision of Bacteria.

Our results, though descriptive, suggest that even at the small spatial scale here studied, local environmental factors are crucial in shaping the BCC. The large heterogeneity observed among very close ecosystems in the Altiplano resemble that found among rock pools (Langenheder and Ragnarsson, 2007) and hydrothermal springs (Bowen De León et al., 2013), where environmental factors and historical events shape the BCC. Though, salinity is known to be a strong selective factor for bacteria (Langenheder et al., 2003), it remains to be tested what environmental factors shape the different BCC of the ponds in the bofedal. Finally, our study highlights peatland ponds of the Altiplano as a potential source of novel microbial diversity that remains to be explored. This a further reason to preserve these unique and climatically sensitive 
environments, which in other regions of Chile and South America are already under strong human pressure (Valdivia et al., 2013).

\section{AUTHOR CONTRIBUTIONS}

PA, CD, and RS, collected the samples, PA and EA prepared the samples for pyrosequencing, PA run the bioinformatic analysis, PA and RS wrote most of the manuscript, and CD and EA contributed with the writing. CD and RS obtained funding for the project. All authors have read and approved this manuscript.

\section{FUNDING}

This work was supported by the National Commission for Scientific and Technological Research (FONDECYT Nr.

\section{REFERENCES}

Bowen De León, K., Gerlach, R., Peyton, B. M., and Fields, M. W. (2013). Archaeal and bacterial communities in three alkaline hot springs in heart lake geyser basin, yellowstone national park. Front. Microbiol. 4, 330. doi: 10.3389/fmicb.2013.00330

Brocke, H. J., Wenzhoefer, F., de Beer, D., Mueller, B., van Duyl, F. C., and Nugues, M. M. (2015). High dissolved organic carbon release by benthic cyanobacterial mats in a Caribbean reef ecosystem. Sci. Rep. 5, doi: 10.1038/srep08852

Brown, C. T., Hug, L. A., Thoms, B. C., Sharon, I., Castelle, C. J., Singh, A., et al. (2015). Unusual biology across a group comprising more than $15 \%$ of domain Bacteria. Nature 523, 208-211. doi: 10.1038/nature 14486

Céréghino, R., Biggs, J., Oertli, B., and Declerck, S. (2008). The ecology of European ponds: defining the characteristics of a neglected freshwater habitat. Hydrobiologia 597, 1-6. doi: 10.1007/s10750-007-9225-8

Cooper, D. J., Kaczynski, K., Slayback, d., and Yager, K. (2015). Growth and organic carbon production in peatlands dominated by Distichia muscoides, Bolivia, South America. Arct. Antarc. Alp. Res. 47, 505-510. doi: 10.1657/AAAR0014-060

De Meester, L., Declerck, S., Stoks, R., Louette, G., Van de Meutter, F., De Bie, T., et al. (2005). Ponds and pools as model system in conservation biology, ecology and evolutionary biology. Aquat. Conserv: Mar. Freshw. Ecosyst. 15, 715-725. doi: 10.1002 /aqc.748

Demergasso, C., Dorador, C., Meneses, D., Blamey, J., Cabrol, N., Escudero, L., and Chong, G. (2010). Prokaryotic diversity pattern in high-altitude ecosystems of the Chilean Altiplano. J. Geophys. Res. 115, G00D09, doi: 10.1029/2008JG000836

Donachie, S. P., Bowman, J. P., and Alam, M. (2004). Psychroflexus tropicus sp. nov., an obligately halophilic Cytophaga-Flavobacterium-Bacteroides group bacterium from an Hawaiian hypersaline lake. Int. J. Syst. Evol. Microbiol. 54, 935-940. doi: 10.1099/ijs.0.02733-0

Dorador, C., Busekow, A., Vila, I., Imhoff, J., and Witzel, K. (2008a). Molecular analysis of enrichment cultures of ammonia oxidizers from the Salar de Huasco, a high altitude saline wetland in northern Chile. Extremophiles 12, 405-414. doi: 10.1007/s00792-008-0146-X

Dorador, C., Meneses, D., Urtuvia, V., Demergasso, C., Vila, I., Witzel, K.P., et al. (2009). Diversity of Bacteroidetes in high-altitude saline evaporitic basins in northern Chile. J. Geophys. Res. 114, G00D05. doi: 10.1029/2008JG 000837

Dorador, C., Vila, I., Imhoff, J. F., and Witzel, K.-P. (2008b). Cyanobacterial diversity in Salar de Huasco, a high altitude saline wetland in northern Chile: an example of geographical dispersion? FEMS Microbiol. Ecol. 64, 419-432. doi: 10.1111/j.1574-6941.2008.00483.x

Dorador, C., Vila, I., Remonsellez, F., Imhoff, J. F., and Witzel, K.-P. (2010). Unique clusters for Archaea in Salar de Huasco, an athalassohaline evaporitic basin of
1140179; CONICYT Nr.1110953, Chile) to CD and by the Austrian Science Fund (FWF, P24442-B25) to RS.

\section{ACKNOWLEDGMENTS}

We thank Josef Franzoi, Salvador Morales-Gomez, and Gry Larsen for assistance with water chemical analyses, Hannes Peter for comments and for producing supplementary Figure S4, and Irma Vila for providing resources for the work in Chile to RS.

\section{SUPPLEMENTARY MATERIAL}

The Supplementary Material for this article can be found online at: http://journal.frontiersin.org/article/10.3389/fmicb. 2016.00976

the Chilean Altiplano. FEMS Microbiol. Ecol. 73, 291-302. doi: 10.1127/18639135/2013/0393

Dorador, C., Vila, I., Witzel, K. P., and Imhoff, J. F. (2013). Bacterial and archaeal diversity in high altitude wetlands of the Chilean Altiplano. Fund. Appl. Limnol. 182, 135-159. doi: 10.1007/s00239-005-0176-2

Evans, J., Sheneman, L., and Foster, J. (2006). Relaxed Neighbor Joining: a fast distance-based phylogenetic tree construction method. J. Mol. Evol. 62, 785792. doi: 10.1016/S0031-0182(03)00269-4

Garreaud, R., Vuille, M., and Clement, A. C. (2003). The climate of the Altiplano: observed current conditions and mechanisms of past changes. Palaeogeogr. Palaeoclim. Palaeoecol. 194, 5-22. doi: 10.1016/S0031-0182(03) 0026-4

Goordial, J., Davila, A., Lacelle, D., Pollard, W., Marinova, M. M., Greer, C. W., et al. (2016). Nearing the cold-arid limits of microbial life in permafrost of an upper dry valley, Antarctica. ISME J. doi: 10.1038/ismej. 2015.239

Hahn, M. (2006). The microbial diversity of inland waters. Curr. Opin. Biotechnol. 17, 256-261. doi: 10.1016/j.copbio.2006.05.006

Hammer, Ø., Harper, D. A. T., and Ryan, P. D. (2001). PAST: paleontological statistics software package for education and data analysis. Palaeontol. Electronica 4, 1-9. http://palaeo-electronica.org/2001_1/past/issue1_01.htm

Hanson, C., Fuhrman, J., Horner-Devine, M. C., and Martiny, J. (2012). Beyond biogeographic patterns: processes shaping the microbial landscape. Nat. Rev. Microbiol. 10, 497-506. doi: 10.1038/nrmicro2795

Helms, J. R., Stubbins, A., Ritchie, J. D., Minor, E. C., Kieber, D. J., and Mopper, K. (2008). Absorption spectral slopes and slope ratios as indicators of molecular weight, source, and photobleaching of chromophoric dissolved organic matter. Limnol. Oceanogr. 53, 955-969. doi: 10.4319/lo.2008.53. 3.0955

Holgerson, M. (2015). Drivers of carbon dioxide and methane supersaturation in small, temporary ponds. Biogeochemistry 124, 305-318. doi: 10.1007/s10533015-0099-y

Kirchman, D. L. (2002). The ecology of Cytophaga-Flavobacteria in aquatic environments. FEMS Microbiol. Ecol. 39, 91-100. doi: 10.1016/s01686496(01)00206-9

Langenheder, S., Kisand, V., Wikner, J., and Tranvik, L. J. (2003). Salinity as a structuring factor for the composition and performance of bacterioplankton degrading riverine DOC. FEMS Microbiol. Ecol. 45, 189-202. doi: 10.1016/S0168-6496(03)00149-1

Langenheder, S., and Ragnarsson, H. (2007). The role of environmental and spatial factors for the composition of aquatic bacterial communities. Ecology 88, 2154-2161. doi: 10.1890/06-2098.1

Letunic, I., and Bork, P. (2011). Interactive tree of life v2: online annotation and display of phylogenetic trees made easy. Nucleic Acids Res. 39, W475-W478. doi: 10.1093/nar/gkr201 
Lozupone, C., and Knight, R. (2005). UniFrac: a new phylogenetic method for comparing microbial communities. Appl. Environ. Microbiol. 71, 8228-8235. doi: 10.1128/AEM.71.12.8228-8235.2005

Marquez-Garcia, M., Vila, I., Hinojosa, L., Mendez, M., Carvajal, L., and Sabando, M. (2009). Distribution and seasonal fluctuations in the aquatic biodiversity of the southern Altiplano. Limnologica 39, 314-318. doi: 10.1016/j.limno.2009.06.007

McClain, M., Boyer, E., Dent, C., Gergel, S., Grimm, N., Groffman, P., et al. (2003). Biogeochemical hot spots and hot moments at the interface of terrestrial and aquatic ecosystems. Ecosystems 6, 301-312. doi: 10.1007/s10021-003-0161-9

Neave, M., Luter, H., Padovan, A., Townsend, S., Schobben, X., and Gibb, K. (2014). Multiple approaches to microbial source tracking in tropical northern Australia. MicrobiologyOpen 3, 860-874. doi: 10.1002/mbo3.209

Nelson, W. C., and Stegen, J. C. (2015). The reduced genomes of Parcubacteria (OD1) contain signatures of a symbiotic lifestyle. Front. Microbiol. 6:713. doi: 10.3389/fmicb.2015.00713

Peura, S., Eiler, A., Bertilsson, S., Nyänen, H., Tiierola, M., and Jones, R. I. (2012). Distinct and diverse anaerobic bacterial communities in boreal lakes dominated by candidate division OD1. ISME J. 6, 1640-1652. doi: 10.1038/ismej.2012.21

Pujalte, M. J., Lucena, T., Ruvira, M. A., Ruiz, D., and Macián, M. C. (2014). “The family Rhodobacteraceae," in The Prokaryotes, eds E. Rosenberg, E. F. DeLong, S. Lory, E. Stackebrandt, and F. Thompson (New York, NY: Springer): 439-512.

Rinke, C., Schwientek, P., Sczyrba, A., Ivanova, N. N., Anderson, I. J., Cheng, J.-F., et al. (2013). Insigths into the phylogeny and coding potential of microbial dark matter. Nature 499, 431-437. doi: 10.1038/nature12352

Risacher, F., Alonso, H., and Salazar, C. (2003). The origin of brines and salts in Chilean salars: a hydrochemical review. Earth Sci. Rev. 63, 249-293. doi: 10.1016/S0012- 8252(03)00037-0

Schloss, P., Gevers, D., and Westcott, S. (2011). Reducing the effects of PCR amplification and sequencing artifacts on 16S rRNA-based studies. PLOS ONE 6, e27310. doi: 10.1371/journal.pone.0027310

Seufferheld, M., Alvarez, H. M., and Farias, M. E. (2008). Role of polyphosphates in microbial adaptation to extreme environments. Appl. Environ. Microbiol. 74, 5867-5874. doi: 10.1128/AEM.00501-08

Sobek, S., Tranvik, L., Prairie, Y., Kortelainen, P., and Cole, J. (2007). Patterns and regulation of dissolved organic carbon: an analysis of 7,500 widely distributed lakes. Limnol. Oceanogr. 52, 1208-1219. doi: 10.4319/lo.2007.52.3.1208
Squeo, F., Warner, B., Aravena, R., and Espinoza, D. (2006). Bofedales: high altitude peatlands of central Andes. Rev. Chil. Nat. 79, 245-255. doi: 10.4067/s0716078x2006000200010

Turner, S., Pryer, K. M., Miao, V. P. W., and Palmer, J. D. (1999). Investigating deep phylogenetic relationships among cyanobacteria and plastids by small subunit rRNA sequence analysis. J. Euk. Microbiol. 46, 327e38. doi: 10.1111/j.15507408.1999.tb04612.x

Valdivia, C., Thibeault, J., Gilles, J. L., García, M., and Seth, A. (2013). Climate trends and projections for the Andean Altiplano and strategies for adaptation. Adv. Geosci. 33, 69-77. doi: 10.5194/adgeo-33-69-2013

van der Gucht, K., Cottenie, K., Muylaert, K., Vloemans, N., Cousin, S., Declerck, S., et al. (2007). The power of species sorting: local factors drive bacterial community composition over a wide range of spatial scales. Proc. Nat. Acad. Sci. U.S.A 104, 20404-20409. doi: 10.1073/pnas.0707 200104

Vila, I., Pardo, R., and Scott, S. (2007). Freshwater fishes of the Altiplano. Aquat. Ecosyst. Health Manag. 10, 201-211. doi: 10.1080/14634980701351395

Wood, A. M., Miller, S. R., Li, W. K. W., and Castenholz, R. W. (2002). Preliminary studies of cyanobacteria, picoplankton, and virioplankton in the Salton Sea with special attention to phylogenetic diversity among eight strains of filamentous cyanobacteria. Hydrobiologia 473, 77-92. doi: 10.1023/A:1016573 400010

Zwart, G., Crump, B., Kamst-van Agterveld, M., Hagen, F., and Han, S. (2002). Typical freshwater bacteria: an analysis of available 16S rRNA gene sequences from plankton of lakes and rivers. Aquat. Microb. Ecol. 28, 141-155. doi: $10.3354 / \mathrm{ame} 028141$

Conflict of Interest Statement: The authors declare that the research was conducted in the absence of any commercial or financial relationships that could be construed as a potential conflict of interest.

Copyright (c) 2016 Aguilar, Acosta, Dorador and Sommaruga. This is an open-access article distributed under the terms of the Creative Commons Attribution License (CC BY). The use, distribution or reproduction in other forums is permitted, provided the original author (s) or licensor are credited and that the original publication in this journal is cited, in accordance with accepted academic practice. No use, distribution or reproduction is permitted which does not comply with these terms. 